\title{
Financial Literacy of Rural Population as a Determinant of Saving Behavior in Kazakhstan
}

\author{
* Sholpan Gaisina ${ }^{1}$, Lyazzat Kaidarova ${ }^{2}$, \\ ${ }^{1}$ Business School, Hochschule Stralsund, Zur Schwedenschanze 15, 18435, Stralsund, Germany \\ ${ }^{2}$ Economic Faculty, Innovative Eurasian University, Lomov Street 45, Pavlodar, Kazakhstan
}

\begin{abstract}
In rural Kazakhstan, the credit and insurance services are limited and the state support is weak. Therefore, households' saving is crucial to provide an insurance against the economic and social shocks. The main goal of this study is to contribute to the literature on financial literacy in emerging economies, namely, the effect of financial literacy on saving rates of rural population. Being well educated not always means to be financial literate and make efficient decisions regarding one's own finance. People with a lower formal education level but with better experience in consuming financial products could be better prepared for making financial decisions including those related to savings. In this paper other socio-economic determinants of saving rates were taken into account, such as an income level, family size and an employment status. This research was carried out in Pavlodar region of Kazakhstan, and the data collection took place in spring 2014. In total, 405 households were surveyed. Results of the analysis show that if a respondent gives at least one correct answer, it positively affects the saving rates as well as one can observe that the higher the financial literacy level, the higher are the saving rates. Availability of state supported financial education programs for rural people will significantly contribute to the financial literacy improvement. At the same time, providing various and appropriate financial products in rural areas will motivate rural people to search for new knowledge and require authorities to intensify activities in this field.
\end{abstract}

Key words: finance, literacy, rural, savings rate, credit.

\section{Introduction}

Financial system becomes increasingly sophisticated, and to be able to make efficient and informed judgments aimed to promote well-being, market participants need to be able to understand correctly financial and other relevant information provided by financial institutions (United States Senate, 2003).

Xiao considers financial behavior as human behavior related to money management which includes budgeting, spending, borrowing, saving and investing, and risk managing (Xiao, 2008). Individuals, who are more financially literal, tend to make fewer mistakes in financial decisions, and as a result are in better financial conditions (Meier \& Sprenger, 2008).

Rural households in Kazakhstan could be determined as semi-commercial agricultural entities which are not legally registered, however, supplying a large portion of agricultural products for the domestic market: vegetables and fruits (about 80\%), meat and dairy production (about 90\%) dominate in rural households. Thus, being treated as physical persons, rural households are excluded from all the state supported programs and preferential state credit lines aimed at farms and agricultural enterprises. Nevertheless, these agricultural entities need to be able to maintain their wellbeing as well as to invest in productivity and quality. However, as in many other developing and transition economies, rural population find themselves excluded or dissuaded from the formal financial sector (Nguyen, 2007). As a result, in most cases personal family savings could be the only source of investments.

One could expect that higher levels of financial literacy will positively affect saving rates, people who can make informed judgments regarding their financial circumstances would be able to

\footnotetext{
* Corresponding Author's email:

Sholpan.Gaisina@hochschule-stralsund.de
} 
initiate different saving plans and insure their future.

The paper is aimed at contribution to the understanding of rural household saving behavior in relation to the level of financial literacy. It is the first study to estimate rural household saving for Kazakhstan using primary data and econometric tools; overall, only a few studies have dealt with the relationship between financial literacy and saving rates in the context of rural areas in an emerging market.

This paper aimed to answer the following questions:

a. Whether being financially literate affects savings behavior,

b. Whether highly financially literate people save more.

Micro-econometric analysis helps to assess the importance of the level of financial literacy and a number of other household characteristics for the decision making towards savings rate of the rural population in Kazakhstan. The analysis is based on the data collected by a survey conducted in 2014 in Pavlodar region of Kazakhstan.

One reason for the limited literature on the determinants of rural household saving in Kazakhstan is lack of appropriate data, in particular, data sets containing information on household financial literacy, income, savings and wealth. Such datasets are not readily available in most transition countries, including Kazakhstan. Therefore, this survey could be considered unique.

The rest of this paper is structured as follows: Section 2 presents an overview of literature on financial literacy and savings in rural areas; Section 3 provides information on financial education in Kazakhstan; Sections 4 and 5 present a survey, define variables, and provide a methodology description. Section 6 reports results of a micro- econometric analysis, Section 7 provides some discussions and Section 8 outlines conclusions.

\section{Literature Review Definition of financial literacy}

There are various definitions of financial literacy presented in literature. According to Policy Research Initiative (PRI, 2004), financial literacy is the ability to understand and distinguish financial options, feel comfortable talking on personal finance topics, make decisions protecting against future insecurities as well as be prepared to solve every day financial problems effectively. PRI (2005) considers financial literacy as a concept that "emphasizes objective knowledge on specific topics related to money, economics, or financial matters, and subjective measures of self- reported confidence". Financial literacy could be also defined as an ability of a person to understand and process information to be able to make a proper financial decision (Gaurav \& Singh, 2012). Financial literacy is very often associated with knowledge on saving and borrowing, which means possessing sound financial management skills and habits in turn (Hogarth, Hilgert \& Schuchardt, 2002).

When talking about financial literacy, one should keep in mind that it is not about just individual retirement security, but indeed about the stability of the global financial system (Lusardi \& Mitchell, 2011). The financial decisions could range from simple everyday spending to making choices regarding banking products, investments, and saving ways (PRI, 2005). It is believed that financial literacy affects financial security, well-being, and prosperity of people (PRI, 2005). Financial literacy could be considered from two points of view, the first one is related to the financial knowledge which includes such things as understanding the concept of interest rate, inflation rate, different types of loans etc.; the second point related to a confidence component such as a self-estimated level of financial knowledge and self-reported abilities to make effective financial decisions (PRI, 2004).

Even people with limited resources, in particular, from rural areas, who would never afford to have a mortgage or own a big amount of money, need to be able to perform some financial calculations, because their incomes are highly vulnerable and difficult to be predicted. Such low-income population needs to be financially literate to be able to make decisions without the expertise of paid consultants (Willis, 2008).

It is generally assumed that financial literacy could change people's behavior towards financial services and products, however, as West emphasizes financial literacy does not provide sustained changes in and optimal of financial behavior (West, 2012).

Financial education is aimed to provide people with such knowledge which could help them to maintain household budgets, choose among various savings plans, control their debts, as well as be prepared for making investment decisions (United States Senate, 2003).

According to Hogarth (2006), financial education is considered differently by different people. Some people would esteem themselves as financially educated if they possess quite a broad range of financial knowledge as understanding complicated macroeconomic issues and their effect of everyday household financial decisions. At the same time, others would focus exclusively on basic routine money management. However, apparently financial 
education covers both macro and narrow ranged topics.

Financially literate people, according to Bhushan \& Medury (2013), are “... able to sail through tough financial times" because financial literacy directly correlates with positive financial behavior.

\section{Savings in rural areas}

The literature on savings behavior of rural population in transition and developing economies describes a broad range of factors, which determine savings; those factors could be clustered according to the concepts of consumption smoothing and precautionary savings (Denizer, Wolf \& Ying, 2000). Savings are an important way of improving wellbeing, insuring against times of shock, and providing a buffer to help people cope in times of crisis (Zeller \& Sharma, 2000). Three main theories have been widely used in studies on household saving behavior: The Life Cycle Hypothesis offered by Modigliani (Modigliani, 1963), Kynesian theory (Keynes, 1936) and Permanent Income Hypothesis by Friedman (Friedman, 1957). According to these theories saving entails an inter-temporal reallocation of resources. These theories provide a number of reasons for such reallocation of resources by a household (Browning \& Lusardi, 1996; Kennickell \& Lusardi, 2003). However, they rarely focus on low-income rural households in developing and transition economies, little is known about the true determinants of savings in this group (Beverly \& Sherraden, 1999).

In transition economies with underdeveloped credit and insurance markets in rural areas, household savings are a crucial determinant of welfare. To be able to smooth out unexpected variations in their income, rural households are forced to resort to savings, which are usually only means to accumulate assets in the absence of formal financial markets. Indeed, savings become one of the main vehicles of social mobility and of enhancing future income-earning possibilities. Additionally, it is well known that savings are one of the most important determinants of economic growth because savings are a crucial source for investments (Attanasio \& Székely, 2000). The inability, willingness and opportunity of households to save over time can therefore significantly influence the rate and sustainability of capital accumulation and economic growth in developing countries (Bautista \& Lamberte, 1990).

One can expect that once savings of rural households rise, more opportunities for growth in the agricultural sector of the economy will be created (Attanasio \& Székely, 2000). Thus, directly, savings could be used for investments. Indirectly, saving indicates repayment abilities, and results in an increase of credit rating and could be used as collateral in a credit market (Brata, 1999).

Education affects savings performance by influencing the level of income and the options for asset accumulation available to the individual. Bernheim and Garrett in their study showed that saving rates increase with education, at the same time the study emphasized that low-income individuals have less access to financial education (Bernheim \& Garrett, 1996). Other studies, for instance, by Bernheim and $\mathrm{Ng}$ suggest that most Americans have relatively limited financial knowledge (Bernheim, 1995; Ng, 1992). Solmon (1975) and Kaufmann (1984) found that financial knowledge varied with education, and Bernheim and Scholz (1993) found that the financial behavior of college-educated individuals reflected more sophisticated planning than that of lessereducated individuals. It is obvious, that the majority of rural households in transition economies, being low-income households, need to be provided with special financial education programs.

The most significant determinant of household saving behavior is the level of income. However, the determinants of savings include but are not limited to the income of the household. A number of authors used as determinants of saving behavior non-financial assets such as real estate, cars, durable goods, and animal stock. Kulikov et al. concluded that there is no significant effect of ownership of real estate on saving, while ownership of durable consumer goods reduces household savings. He emphasizes that the stock ownership of various financial assets and liabilities, and the accessibility to liquid assets affect saving negatively. Nevertheless, if wealth is in the form of productive assets such as farmland, it can have a positive impact on saving. Larger land ownership helps the farmers to benefit from economies of scale and, hence, provide higher production and earning (Kulikov, Paabut \& Staehr, 2007).

Similarly, the type of work determines the regularity of income. Wage employment, selfemployment, or casual employment provides a source of income, of which a portion can be saved. Income is identified as a risk factor in the precautionary savings theory. According to Kennickell \& Lusardi "This theory predicts that risk depresses consumption and increases the accumulation of wealth" (Kennickell \& Lusardi, 2003).

In addition to variables like income, income shocks, wealth and financial exposure, saving preferences also will generally depend on a range of characteristics such as the size and composition of the household as well as the age and education of individuals in the household (Denizer, Wolf \& Ying, 2000). According to Gersovitz, there are at least three 
approaches to conceptualizing the role of the family in the saving process: (1) as a veil concealing purely individualistic behavior; (2) as a substitute for absent or imperfect markets; or (3) as the fundamental and indecomposable decision unit (Gersovitz, 1995).

There are a few studies considering credit as a factor influencing savings. Some studies support an economic theory, which states that access to credit could reduce incentives to save, since some current savers will reduce their saving since future needs can be financed more easily through credit. So, according to the International Monetary Fund (IMF) survey, an improvement in availability of credit is one cause cited for decline in savings in many industrial countries (Terrones \& Carderelli, 2005). It means that the improvement in credit access would negatively affect savings behavior. However, in his empirical study Rogg showed that savings are positively related to credit access (Rogg, 2000).

Therefore, understanding of factors that affect the savings performance of households is a necessary step to the formulation of an effective social development policy in developing and transition economies (Chowa, 2006).

\section{Financial education and financial literacy in Kazakhstan}

Following global trends, policy makers in Kazakhstan recognized the importance of financial education and financial literacy for people. A number of state supported programs and initiatives has been launched since 2011, the year when according to the Presidential decree the Committee on protection of the rights of consumers of financial services under the National Bank of the Republic of Kazakhstan was created. The Committee was designed to secure proper protection of the rights and interests of consumers of financial services (CIS (Construction Industry Scheme) -Legislation, 2013).

Among other tasks, the Committee is responsible for the development of specific instruments aimed to improve financial education of Kazakhstani citizens. These instruments include such measures as using mass media resources for promotion of basic financial knowledge among Kazakhstani citizens, delivering up-to-date information through the Committee's website, conducting trainings for financial services' consumers.

In 2008, a program "Informational and educational centers" (Centers) was launched in all regions of Kazakhstan as well as in cities Astana and Almaty. Centers provide free of charge seminars and consulting for people, and since 2008 they have served about 360,000 people from all over the country, or $2.7 \%$ of adult population (RFCA, 2015). Additionally, in 2009, a TV training talk show "Vash vykhod" (Your solution) was launched on a weekly basis. This TV program discusses such issues as banking, pension,

Results of surveys, in \%

Table 1

\begin{tabular}{|l|c|c|c|}
\hline & RFCA survey & ICEL survey & $\begin{array}{c}\text { Pavlodar region, rural } \\
\text { areas, own survey }\end{array}$ \\
\hline Ever used any type of financial services & 62.5 & & 72 \\
\hline Ever used any type of formal loans & 32 & & 65 \\
\hline Ever used consumer loans & & & 52 \\
\hline Have a deposit account & 8.5 & 44 & 21 \\
\hline Keep savings at home & & & 37 \\
\hline Save exclusively in livestock & & & 37 \\
\hline Do not keep records on family budget & 55 & & 69 \\
\hline Self-estimation of financial literacy as high & & & \\
\hline Sources of financial knowledge & & & \\
\hline TV programs & 36.9 & & 84 \\
\hline Internet resources & 24.3 & & 15 \\
\hline Newspapers & 20 & & \\
\hline Consultancy & 23 & & 27 \\
\hline Special training and workshops & 17.1 & & 23 \\
\hline
\end{tabular}

Sources: RFCA, NFDFS (National Fund for the Development of Financial Services), Own calculations. 
insurance, and securities market. Participants of this talk show are people with real stories, experts, and analysts.

According to the survey conducted by RFCA (Regional Financial Center Almaty, Kazakhstan), about $40 \%$ of respondents had never had any experience dealing with financial instruments and only $8 \%$ reported to have a deposit account in the bank (RFCA, 2015). Another survey conducted in 2014 in all 14 regions of Kazakhstan as well as in Almaty and Astana cities by the non-government fund "International Centre of Economic Literacy, Kazakhstan" (ICEL) shows that around $44 \%$ of the Kazakh population prefers to keep their savings at home; around $38 \%$ of respondents do not keep record of family budget while $43 \%$ of the respondents were not aware of deposit insurance mechanisms. According to the same survey, only $6 \%$ of respondents were aware of the maximum value of the deposits insured and $63 \%$ admitted that they usually ran out of money before next salary payments. The results of the survey showed that about $44 \%$ indicated their financial literacy level as satisfying to be able to make decisions related to formal financial services. However, according to the data, $67 \%$ of respondents believe that they would not face any punishments if they failed to meet the legal obligations of a formal loan and $50 \%$ indicated that they did not plan to pay their loans back (Interfax-Kazakhstan, 2015). The data on Kazakhstani population financial literacy and data based on the survey in Pavlodar region conducted in 2014 are summarized in Table 1.

\section{Data source and description of variables}

The study uses data from rural areas of Kazakhstan. The study took place in Pavlodar region of Kazakhstan in the spring of the year 2014. The survey provided information about 405 rural households from villages of four rural districts located in different distances from the city. The survey collected information on financial literacy (knowledge of interest rate, understanding of inflation, and understanding of mortgage), as well as information on financial services (the use of bank accounts and formal credit). In this analysis, only respondents who make savings were included, 343 respondents or $84.67 \%$ of the sample. The dependent variable is a savings rate varying from $0 \%$ to more than $25 \%$ of income. The information covers such areas as: a measure of the objective and subjective financial literacy, whether the respondent has any experience dealing with formal financial institutions, their income situation. The dataset provides information on respondents' socio-demographic characteristics and their opinion regarding financial education. This survey has questions concerning whether the individual has got a loan from a formal financial institution for last five years, information on keeping records of the family budget, as well as a question on the respondents' opinion what the primary attention should be when someone compares banks in order to choose to take credit from or to make deposit in.

The sample consists of rural people and therefore it is of a particular interest for the research questions concerning financial literacy, because rural people in Kazakhstan are in a very vulnerable financial position.

To measure basic financial literacy the questions adopted from the "Supplementary Questions: Optional Survey Questions for the OECD (Organization for Economic Co-operation and Development) INFE (International Network on Financial Education) Financial Literacy Core Questionnaire" (OECD, 2012) were used. In the questionnaire three questions were included:

1. Suppose you had USD 100 in a savings account and the interest rate was $2 \%$ per year. After 5 years, how much do you think you would have in the account if you left the money to grow?
a. More than USD 102
b. Exactly USD 102
c. Less than USD 102
d. No answer

2. Imagine that the interest rate on your savings account was $1 \%$ per year and inflation was $2 \%$ per year. After 1 year, how much would you be able to buy using money from this account?
a. More than today
b. Exactly the same
c. Less than today
d. No answer

3. A 15-year mortgage typically requires higher monthly payments than a 30-year mortgage, but the total interest paid over the life of the loan will be less.
a. True
b. False
c. No answer

Those who were not able to give an answer or gave the wrong ones account for $20 \%$ of asked individuals, only $64 \%$ demonstrated an understanding of interest rate concept and only $12 \%$ could answer a simple question about inflation. Those who could give a correct answer on a question regarding mortgage accounted for $46 \%$. In general, respondents with one, two, or three correct answers accounted for $42 \%$, $34 \%$, and $4 \%$ respectively.

\section{Methodology}

The following hypotheses are formulated, based on the questions and objectives of the research: 


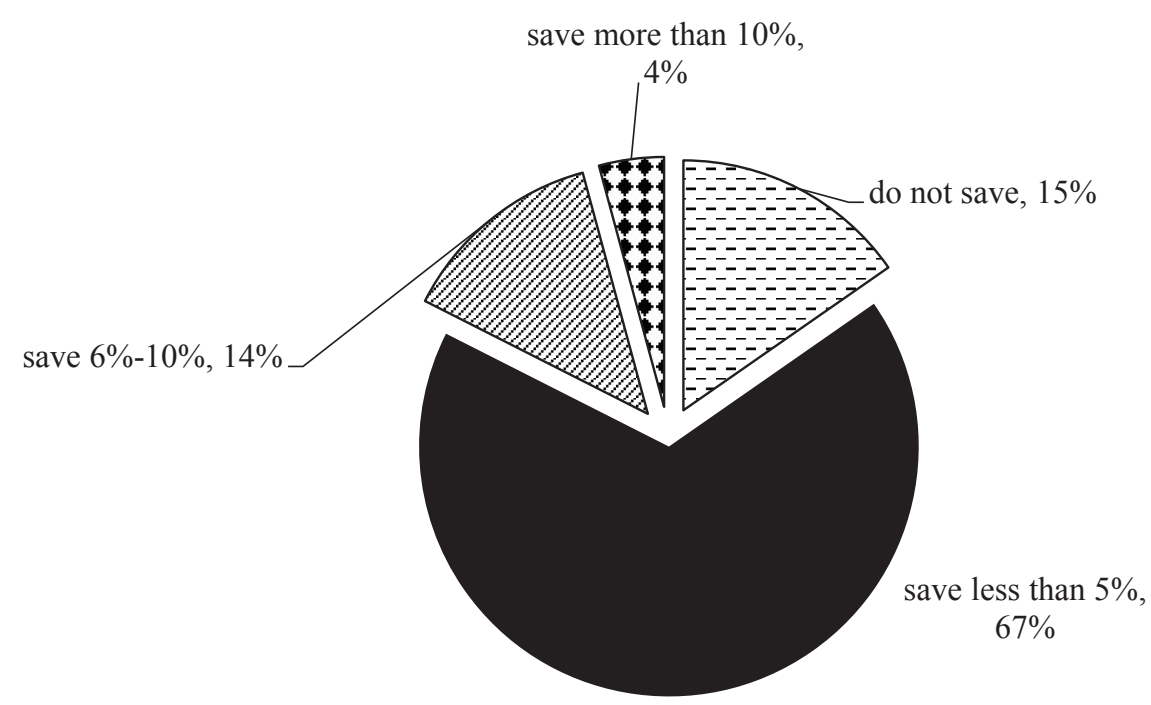

Figure 1. Distribution of respondents according to the level of savings.

H 1. Following Hogarth, Anguelov \& Lee (2005) we hypothesize that there is a positive relation between an ability to manage one's own finance and financial literacy.

H 2. We assume that financial literacy has a significant impact on saving rates, as financial skills and knowledge enable people to make more substantive financial plans and wiser allocation of their financial resources (Mahdzan \& Tabiani, 2013).

H 3. Respondents with higher income would be able to save greater portion and those who have a deposit account in the financial institution supposedly would have more incentives to save.

It is necessary to mention that the respondents with the lowest saving rate of $1-5 \%$ take the biggest share, more than $67 \%$, those who indicated their savings as more than $10 \%$ of their income make just $4 \%$ of all the respondents (Figure 1).

\section{Dependent variable}

The analysis considers the dependence of saving rates on some factors including the level of financial literacy. The respondents were asked to indicate the savings rate answering a question "What is your average monthly savings (if any) in percentage to the income?" They had the options as follows:
a. $0 \%$
b. $1-5 \%$
c. $6-10 \%$
d. $11-15 \%$
e. $16-20 \%$
f. $21-25 \%$
g. above $25 \%$

The variable "SAVING RATE" was coded as "0" - no savings, " $1 \%-5 \% "-1$, " $6 \%-10 \% "-2$, " $11 \%-15 \% "-3$, "16\%-20\%" - 4, " $20 \%-25 \% "-5$, and " above $25 \% "-6$.

\section{Explanatory variables}

A choice of explanatory variables was based on recommendations of Kempson (2009) as well as studies of Lusardi \& Mitchell (2010 and 2011), and Klapper, Lusardi \& Panos (2013). The explanatory variables include:

a. level of financial literacy measured by means of simple financial questions. Four options of financial literacy were considered:

- How does each of three questions affect the level of savings?

- How does an increase in the number of correct answers affect the level of savings?

- Whether those who correctly answered all three questions indicate higher saving rates?

- Whether any given correct answer affects the level of saving?

b. a set of variables measuring financial inclusion and financial experience of the respondents: whether the respondent had credit from the formal financial institution for last five years, whether the respondent has such a habit in his/her family to keep records on the family budget, and how many formal financial institutions are available in the area;

c. a set of variables characterizing sociodemographic status of the respondent, such variables as gender, age, educational level, type of employment, and a family size; 
d. a variable indicating a level of financial literacy based on individual's self-estimation

e. the income level of a respondent.

We used the following independent variables (predictors) for the four regressions:

a. ANY CORRECT - a binary variable which refers to the respondent giving a correct answer on any questions provided, 0 - no correct answer, 1- at least one correct answer;

b. ALL THREE CORRECT - a binary variable refers to the respondents who provided correct answers on all three questions, 0 - less than three correct answers or nor answer, 1- all three answers are correct;

c. ANSWERS - a continuous variable ranging from 0 to 3 , whereby 0 indicates respondents who incorrectly answered all of these questions, while a score of 3 indicates survey participants with a good understanding of fundamental financial concepts;

d. QUESTION INTEREST - this variable is used to estimate how understanding of the basic concept of the interest rate affects the rate of saving by the respondent;

e. QUESTION INFLATION- this variable is used to estimate how understanding of the basic concept of inflation affects the rate of saving by the respondent;

f. QUESTION MORTGAGE - this variable is used to estimate how understanding of the basic concept of mortgage affects the rate of saving by the respondent;

g. GENDER - a binary variable, where " 0 " - a male and " 1 " - a female;

h. AGE - a discrete variable grouped into six levels: $16-24 ; 25-34 ; 35-44 ; 45-54 ; 55-64$; older than 65 ;

i. EDUCATION - a discrete variable grouped into five levels: Tertiary $=1$; Post-secondary/ technical school = 2; High School = 3; Middle School $=4$; Primary School $=5$;

j. CREDIT - a binary variable that refers to the respondents having or nor having got a credit for last five years: with credit $=1$; without credit $=0$;

k. DEPOSIT - a binary variable that refers to the respondent's having or nor having a deposit account at the formal financial institution for last five years: with deposit $=1$; without deposit $=0$;

1. EMPLOYMENT - a discrete variable grouped into five levels: formally employed -1 ; self-employed - 2; unemployed - 3; others (including retirees and students) -4 ;

m. SELFFINLITERACY - a continuous variable that measures the level of financial literacy ascending from " 0 " to " 5 ";

n. FAMILY - indicates a family size, is a continuous variable that measures the number of family members;

o. INCOME - indicates monthly income per household (including all the sources), is a discrete variable grouped into five levels: less than 50,000 KZT - 1, 50,000-70,000 KZT 2, 71,000-100,000 KZT - 3, 101,000-150,000 $\mathrm{KZT}-4$, more than $150,000 \mathrm{KZT}-5$.

\section{Empirical Results}

The ordered probit model was used to investigate the relationship between financial literacy and other socio-economic determinants and saving behavior of respondents.

The regression results show that a correct answer on any provided question increases positively the $\log$ odds of saving rates by 0.4 . However, since the portion of respondents with all three questions, which are answered correctly is very small, this variable is not significant for making a decision regarding the saving.

Moving from "No correct answer" to "three correct answers" increases log odds of saving rates by 1.01. It means that the more financial literate people are, the higher is ability to create and fulfill saving plans.

Table 2 shows that questions concerning an interest rate and an inflation rate are not significant when one makes decision on savings; however, correct answers on the question regarding Mortgage increases positively the log odds of saving rates by 0.62 .

A variable describing self-assessment is not significant when the issue is about savings. Indeed, decisions regarding savings require some specific knowledge and ability to make judgments and prepare long-term saving plans for the household, while selfassessment scores are based mostly on personal feelings regarding financial literacy.

It was expected that a variable Income positively and significantly affects the log odds of saving rates. The higher income is, the higher portion of income that people can save. Having a deposit account at the formal financial institution increases the probability to have the higher level of savings; however, having any experience borrowing from the financial institutions does not affect the decisions regarding savings. Indeed, if a person opens a deposit account, it means she has already saved a particular amount 


\section{Ordered probit model results of financial behavior towards savings}

Table 2

\begin{tabular}{|c|c|c|c|c|c|c|c|c|}
\hline & \multicolumn{2}{|c|}{1} & \multicolumn{2}{|c|}{2} & \multicolumn{2}{|c|}{3} & \multicolumn{2}{|c|}{4} \\
\hline $\begin{array}{l}\text { SAVINGRATE } \\
\text { (only who saves) }\end{array}$ & Coef. & $\begin{array}{l}\text { Std. } \\
\text { Err. }\end{array}$ & Coef. & $\begin{array}{l}\text { Std. } \\
\text { Err. }\end{array}$ & Coef. & $\begin{array}{l}\text { Std. } \\
\text { Err. }\end{array}$ & Coef. & $\begin{array}{l}\text { Std. } \\
\text { Err. }\end{array}$ \\
\hline ANY CORRECT & & & & & & & $0.401 * * *$ & 0.117 \\
\hline $\begin{array}{l}\text { ALL THREE } \\
\text { CORRECT }\end{array}$ & & & & & 0.297 & 0.391 & & \\
\hline ANSWERS & & & $1.001 * * *$ & 0.275 & & & & \\
\hline $\begin{array}{l}\text { QUESTION } \\
\text { INTEREST }\end{array}$ & 0.259 & 0.200 & & & & & & \\
\hline $\begin{array}{l}\text { QUESTION } \\
\text { INFLATION }\end{array}$ & 0.166 & 0.259 & & & & & & \\
\hline $\begin{array}{c}\text { QUESTION } \\
\text { MORTGAGE }\end{array}$ & $0.616 * * *$ & 0.178 & & & & & & \\
\hline SELFFINLIT & 0.069 & 0.072 & 0.085 & 0.071 & 0.073 & 0.07 & 0.051 & 0.071 \\
\hline INCOME & $0.643 * * *$ & 0.093 & $0.600 * * *$ & 0.090 & $0.557 * * *$ & 0.087 & $0.634 * * *$ & 0.092 \\
\hline CREDIT & -0.113 & 0.203 & -0.141 & 0.204 & -0.072 & 0.197 & -0.112 & 0.201 \\
\hline DEPOSIT & $1.964 * * *$ & 0.477 & $1.964 * * *$ & 0.479 & $1.839 * * *$ & 0.467 & $1.949 * * *$ & 0.474 \\
\hline GENDER & -0.162 & 0.176 & -0.125 & 0.176 & -0.114 & 0.171 & -0.138 & 0.174 \\
\hline AGE & $-0.129 *$ & 0.074 & $-0.133^{*}$ & 0.075 & $-0.139 * *$ & 0.072 & $-0.129 *$ & 0.073 \\
\hline FAMILY & -0.030 & 0.050 & -0.034 & 0.050 & -0.040 & 0.049 & -0.028 & 0.049 \\
\hline \multicolumn{9}{|l|}{ EDUCATION } \\
\hline 2 & -0.091 & 0.197 & -0.160 & 0.198 & -0.123 & 0.194 & -0.114 & 0.196 \\
\hline 3 & 0.431 & 0.382 & 0.324 & 0.379 & 0.228 & 0.373 & 0.395 & 0.378 \\
\hline 4 & -0.413 & 0.869 & -0.600 & 0.880 & -0.384 & 0.841 & -0.366 & 0.850 \\
\hline 5 & -3.008 & 650.06 & -3.610 & 651.25 & -3.359 & 648.9 & -3.244 & 651.21 \\
\hline \multicolumn{9}{|l|}{ EMPLOYMENT } \\
\hline 2 & 0.481 & 0.303 & 0.378 & 0.304 & 0.383 & 0.291 & 0.419 & 0.300 \\
\hline 3 & -4.712 & 258.85 & -4.725 & 254.73 & -4.621 & 266.2 & -4.504 & 261.49 \\
\hline 4 & -0.022 & 0.216 & 0.070 & 0.210 & -0.105 & 0.203 & 0.018 & 0.207 \\
\hline
\end{tabular}

Notes: * a significance level of $<10 \%, * *$ a significance level of $<5 \%, * * *$ a significance level of $<0.1 \%$.

of money, since in Kazakhstan one cannot open a deposit account without putting on the account a required minimum amount.

Gender does not play a significant role in making savings; however, a negative sign reveals that moving from the male to the female group decreases the probability to make savings. The more family members the household has, the less probable it is for such a household to increase saving rates; however, this variable is not significant in the decisions to make savings. Such variables as education and an employment status are also not significant. In Kazakhstan, rural people indicating their status as self-employed not necessarily receive much lower income than people who are formally employed, simply some portion of their income could be not officially declared, while formally employed people could openly share information on their official income.

\section{Discussions}

The percentage of female respondents is $50.1 \%$; it corresponds to the national level of $51.85 \%$ in 2013. Women show higher inclination to make saving than men do. The average age in the sample is around $35-44$, it means that the majority of respondents are actively involved in the creating income and 
as a result could make decisions regarding saving for the future. Rural households in Kazakhstan are traditionally multi-child ones, in the sample families with 3-4 members make $36.9 \%$ and with more than four members - 50.1\%. The percentage of formally employed respondents is around $47.7 \%$, self-employed respondents make up about $6 \%$, and unemployed people make $9 \%$, while others including retirees, students and housewives make up about $37.3 \%$ of all the respondents.

The literacy level of respondents is high enough, $44.61 \%$ have tertiary education and $44.3 \%$ have secondary education. According to the World Bank statistics, in Kazakhstan a secondary education enrollment rate in 2012 was $97.1 \%$, while the tertiary enrollment rate was $44.53 \%$.

Among respondents with the secondary and tertiary education majority of respondents is formally employed, $24.5 \%$ and $30.9 \%$ respectively. However, among those who indicated their status as unemployed, the respondents with secondary education make up the biggest share of $54.5 \%$.

The respondents were asked to provide selfmeasurements of their financial knowledge. Most respondents assessed their financial knowledge being above average: $32.7 \%$ of respondents stated their level is $3 ; 29.2 \%$ that their level is 4 and $8.1 \%$ that their level is 10.2 . At the same time, only $8.2 \%$ reported they do not have any knowledge in finance. Most importantly, there is no strong correlation between objective and subjective literacy.

On average, $61.5 \%$ of respondents correctly answered the question on interest rate; 13.1\% correctly answered the question on inflation; and $48.4 \%$ correctly answered the question on mortgage payments. Only $2 \%$ of respondents were not able to provide correct answers.

We can rank respondents who provide correct answers to at least two questions as the "high" financial literacy respondents, a fraction of such respondents is $29.9 \%$. It was expected that the fraction of those who gave correct answers to all three questions is small enough, in our survey it is $3.2 \%$ of all the respondents.

Financially literate respondents are more likely to be female, out of those who provided correct answers on two questions $57.8 \%$ are female. The most financially literate respondents' age is between 33-44 years old.

Financially literate respondents are more likely to have secondary/technical education or tertiary education, $51 \%$ and $37.7 \%$ respectively, from those who gave correct answers on two questions.

Those, whom we consider as the "high" financial literacy respondents, belong to a formally employed group and constitute $53.3 \%$. At the same time, the share of those who are self-employed and provided high scores amounts for $13.3 \%$.

Those who indicated having no income showed the lowest scores of financial literacy. However, there is not a big difference in terms of financial literacy among low and high income groups.

We can observe a moderate positive association between financial literacy and a number of finical institutions operating in the area. In the questionnaire, respondents were asked to indicate whether they have the following financial institutions: branches of commercial banks, post offices, ATMs, Rural Credit Partnerships, Micro Credit Organizations, Insurance companies in their area.

\section{Conclusions}

Findings of this research could be considered as a valuable source of information related to financial literacy in rural areas of Kazakhstan and could be used by politicians for designing measures protecting rural household's financial security. Despite some activities undertaken recently by the Kazakhstani government, rural people still have very limited access to financial education programs; suffer from lack of financial experience due to the insufficient presence of financial institutions in rural areas; have the low level of income which is one of the most important impediments in having access to financial services. Additionally, rural population should not be considered as a homogeneous group.

The study has also shown the financial literacy is a very important determinant of the saving level. If people better understand such basic financial concepts as interest rate, inflation, time value of money, they would wiser use their financial resources and would be able to save larger part of the income.

The findings of this research suggest that if the government aims to increase savings by households, it should increase efforts in improving financial literacy through various education programs provided by both state and private agencies.

\section{References}

1. Attanasio, O.P., \& Székely, M. (2000). Household saving in developing countries inequality, demographics and all that: how different are Latin America and South East Asia? Inter-American Development Bank, p.2.

2. Bautista, R.M., \& Lamberte, M.B. (1990). Comparative saving behavior of rural and urban households in the Philippines. Journal of Philippine Development, 31 (XVII), No.2, p. 150. 
3. Bernheim, B. D. (1995). Do households appreciate their financial vulnerabilities? An analysis of actions, perceptions, and public policy. In Tax Policy and Economic Growth in the 1990s, Washington, DC: American Council for Capital Formation, pp. 1-30.

4. Bernheim, B. D., Garrett, D. M. (1996). The determinants and consequences of financial education in the workplace: evidence from a survey of households (Working Paper No. 5667). Cambridge, MA: National Bureau of Economic Research, p. 4.

5. Bernheim, B. D., \& Scholz, J. K. (1993). Private saving and public policy. In: Tax Policy and the Economy. 7, Ed. James Poterba, MIT Press, p.95.

6. Beverly, S.G, \& Sherraden, M. (1999). Institutional determinants of saving: implications for low-income households and public policy. Journal of Socio-Economics, 28(4), pp.458-460.

7. Bhushan, P., \& Medury, Y. (2013). Financial Literacy and its Determinants. International Journal of Engineering, Business and Enterprise Applications (IJEBEA), pp. 13-145, p.155.

8. Brata, A.G. (1999). Household saving behavior: The case of rural industry in Bantul. Analysis CSIS, 28(1), pp. 75-86.

9. Browning, M., \& Lusardi, A. (1996). Household saving: Micro theories and micro facts. Journal of Economic Literature, 34(4), pp.1797-1855.

10. CIS-Legislation: Presidential Decree of the Republic of Kazakhstan (2013). Retrieved July 22, 2017 from http://cis-legislation.com/ document.fwx?rgn=59213.

11. Chowa, G.A. N. (2006). Savings performance among rural households in Sub-Saharan Africa: The effect of gender. Social Development Issues 28 (2), pp.106-116.

12. Denizer, C., Wolf, H. C., \& Ying, Y. (2000). Household savings in transition economies. Policy Research Working Paper Series 2299, The World Bank, pp.5-6.

13. Friedman, M. (1957). A theory of the consumption function. Princeton: Princeton University Press.

14. Gaurav, S., \& Singh, A. (2012). An Inquiry into the Financial Literacy and Cognitive Ability of Farmers: Evidence from Rural India. Oxford Development Studies, 40, No. 3, pp. 358-380, p.360.

15. Gersovitz, M. (1995). Saving and development. In: Handbook of Development Economics Ed. Chenery, Holli and T.N. Srinivasan, 1, pp. 381424.

16. Hogarth, J.M. (2006). Financial Education and Economic Development Federal Reserve Board,
U.S.A. Paper prepared for "Improving Financial Literacy" International Conference hosted by the Russian G8 Presidency in Cooperation with the OECD 29-30 November 2006, p 3.

17. Hogarth, J.M., Anguelov, C. E., \& Lee J. (2005). Who Has a Bank Account? Exploring Changes, Over Time. 1989-2001 Journal of Family and Economic Issues, 26(1), pp. 7-30, p.10.

18. Hogarth, J. M., Hilgert, M. A., \& Schuchardt, J. (2002). Money managers: The good, the bad, and the lost. Proceedings of the Association for Financial Counseling and Planning Education, p 12.

19. Interfax-Kazakhstan. Retrieved July 22, 2015, from https://www.interfax.kz/?lang=eng\&int $\mathrm{id}=10 \&$ news $\mathrm{id}=8561$.

20. Kaufmann, D. L. (1984). Attitudes, knowledge, and behavior related to savings: a study of Southern Illinois rural women. Unpublished master's thesis, Eastern Illinois University, pp.14-16.

21. Kempson, E. (2009). Framework for the Development of Financial Literacy Baseline Surveys: A First International Comparative Analysis. OECD Working Papers on Finance, Insurance and Private Pensions, No. 1, OECD Publishing, pp.20-24.

22. Kennickell, A., \& Lusardi, A. (2003). Wealth accumulation and the importance of precautionary savings. Retrieved July 22, 2017 from http://citeseerx.ist.psu.edu/viewdoc/down load?DOI $=10.1 .1 .198 .4760 \&$ rep $=$ rep $1 \&$ type $=p$ df, p. 1-5.

23. Keynes, J.M. (1936). The general theory of employment, interest and money. New York: Harcourt, Brace and Co.

24. Klapper, L., Lusardi, A., \& Panos, G.A. (2013). Financial literacy and its consequences: Evidence from Russia during the financial crisis. Journal of Banking \& Finance 37 (2013) pp. 3904-3923.

25. Kulikov, D., Paabut, A., \& Staehr, K. (2007). A microeconometric analysis of household saving in Estonia: income, wealth and financial exposure. Research Department Eesti Pank, pp.13-26.

26. Lusardi, A., Mitchell, O. S. (2008). Planning and financial literacy: How do women fare? American Economic Review: Papers \& Proceedings 2008, 98:2, pp. 413-417.

27. Lusardi, A., Mitchell, O. S., \& Curto, V. (2010). Financial Literacy among the Young. The Journal of Consumer Affairs, pp. 358-380, p.360.

28. Lusardi, A., \& Mitchell, O. S., (2011). Financial literacy around the world: an overview. Journal 
of Pension Economics and Finance, pp 497508., p. 10.

29. Mahdzan, N.S., \& Tabiani, S. (2013). The impact of financial literacy on individual saving: an exploratory study in the Malaysian Context, Transformation in Business and Economics. 12, No 1 (28), p. 41-55.

30. Meier, S., \& Sprenger, C. (2008). Discounting Financial Literacy: Time Preferences and Participation in Financial Education Programs. Public Policy Discussion Papers, Federal Reserve Bank of Boston, No, 07-5, p.2.

31. Modigliani, F. (1963). The life-cycle hypothesis of saving: aggregate implications and tests. American Economic Review, 53(1), pp.55-84.

32. Ng, Y. K. (1992). Do individuals optimize in intertemporal consumption/savings decisions? A liberal method to encourage savings. Journal of Economic Behavior and Organization, 17 (1), pp.102-105.

33. Nguyen, C. H. (2007). Access to credit and borrowing behavior of rural households in a transition. International Conference on Rural finance research: Moving results into policies and practice. FAO Headquarters Rome, Italy 1921 March 2007, p.2.

34. OECD, (2012). Supplementary Questions: Optional Survey Questions for the OECD INFE Financial Literacy Core Questionnaire, pp.3436.

35. PRI (Policy Research Initiative). (2004). Financial Capability and Poverty. Discussion Paper. Prepared by Social and Enterprise Development Innovations for the PRI Project "New Approaches for Addressing Poverty and Exclusion". Ottawa: PRI, Retrieved July 22, 2017 from http://publications.gc.ca/collections/ Collection/PH4-11-2004E.pdf, pp.6-7.

36. PRI (Policy Research Initiative) (2005). Why Financial Capability Matters. Synthesis Report, Prepared by Social and Enterprise Development Innovations for the PRI Project "New Approaches for Addressing Poverty and Exclusion". Report on "Canadians and Their Money: A National Symposium on Financial Capability". Ottawa, June 9-10, 2005, pp.4-
8., Retrieved July 22, 2017 from http://www. fcac-acfc.gc.ca/Eng/resources/researchSurveys/ Pages/WhyFinan-Pourquoi.aspx.

37. Regional Financial Centre of Almaty, RFCA (2015). Enhancement of Investment Culture and Financial Literacy of People of the Republic of Kazakhstan, pp.5-10, Retrieved July 22, 2017 from http://www.azbukafinansov. $\mathrm{ru} /$ files/Kabiev.pdf.

38. Rogg, C.S. (2000). The impact of access to credit on the saving behavior of micro-entrepreneurs: evidence from three Latin American countries. A paper based on a thesis submitted to the University of Oxford in June 1999, p.1.

39. Solmon, L. C. (1975). The relation between schooling and savings behavior: an example of the indirect effects of education. In: Education, Income, and Human Behavior. Ed. F. T. Juster, New York: McGraw-Hill, pp.285-285.

40. Terrones, M, \& Carderelli, R. (2005). Are saving and investment trends fueling global imbalances? IMF Survey - 2005, 34, No.17, Washington DC, IMF, p.276.

41. United States Senate, 2003. The state of financial literacy and education in America: hearing before the Committee on Banking, Housing, and Urban Affairs. United States Senate, One Hundred Seventh Congress, second session, on the state of financial literacy and education in America, February 5 and 6, 2002, 22-23, U. S. Government printing office Washington.

42. West, J. (2012). Financial literacy education and behavior unhinged: combating bias and poor product design. International Journal of Consumer Studies, 36, pp. 523-530, p 523.

43. Willis, L. E. (2008). Evidence and Ideology in Assessing the Effectiveness of Financial Literacy Education. Faculty Scholarship. Paper 197, p.3.

44. Xiao, J.J. (2008). Applying Behavior Theories to Financial Behavior in Handbook of Consumer Finance Research. Xiao JJ (ed.), Springer Link. pp 69-81.

45. Zeller, M., \& Sharma, M. (2000). Many borrow, more save and all insure: Implications for food and micro-finance policy. Food Policy, 25(2), pp.160-161. 